\title{
CHARTING THE LATE CRETACEOUS SEAS: MOSASAUR RICHNESS AND MORPHOLOGICAL DIVERSIFICATION
}

\author{
MARCUS R. ROSS ${ }^{*}, 1$ \\ ${ }^{1}$ Department of Geosciences, University of Rhode Island, Kingston, 02881 U.S.A.
}

\begin{abstract}
Abundant, readily identifiable, and biostratigraphically resolved specimens make mosasaurs ideal candidates to test fluxes in generic richness and morphological trends among marine vertebrates during the late Cretaceous. More than 1800 globally distributed mosasaur specimens are allocated to fifteen substage-level stratigraphically correlated assemblages. These data are quantitatively analyzed to illuminate trends within the group. Following their first appearance in the Cenomanian, mosasaurs experienced a significant radiation in the Coniacian and Santonian. Richness levels continued increasing into the Maastrichtian while mosasaurs incrementally exploited new predatory niches recognized via accumulation of novel dental morphologies. Their extinction at the end of the Cretaceous occurred at the zenith of mosasaur morphological and ecological diversity.
\end{abstract}

\section{INTRODUCTION}

Mosasaurs were generally large, globally distributed apical marine predators known exclusively from late Cretaceous marine shelf and epicontinental sea deposits. Since the discovery of the first mosasaur in 1766 (Mulder, 2003), thousands of specimens have been recovered from Europe, North and South America, Africa, Antarctica, New Zealand, and Japan. The wealth of material, in conjunction with a high level of biostratigraphic refinement, make mosasaurs ideal candidates for tracing the contours of richness and morphologic trends of these marine squamates throughout the Late Cretaceous. This study demonstrates that following their initial origin and radiation, mosasaurs continued a growth in generic richness through at least the early Maastrichtian, followed by overall stable richness levels until their demise at the end of the Maastrichtian. Throughout this time they diversified in predatory behaviors, as deduced from tooth morphology.

Two analyses were conducted. First, I quantitatively analyzed fluxes in mosasaur generic richness during the middle Coniacian through Maastrichtian to determine if richness variations are real or sampling artifacts. Second, I tabulated the distribution of morphological novelties (represented by tooth guilds) among mosasaurs over time to determine the pace of acquisition and distribution of novel adaptive traits.

\section{METHODS: ORGANIZING THE MOSASAUR RECORD}

\section{Biostratigraphic Framework}

Existing high-resolution marine biostratigraphic systems (e.g., ammonites, belemnites, calcareous nannofossils) offer tremendous precision in dating vertebrate fossils. However, due to the comparative rarity of vertebrate remains in any particular microfossil or invertebrate biozone, and the potential for non-recovery of an index taxon due to various geographical, ecological, or human factors, individual biozones are ineffective sampling windows. As a result, most analyses of marine vertebrate diver-

\footnotetext{
${ }^{*}$ Current address: Department of Biology/Chemistry, Liberty University, Lynchburg, Virginia 24502 U.S.A., mross@liberty.edu
}

sity consist either of local/regional studies with high temporal resolution (e.g., Sheldon, 1996; Mulder et al., 1998) or studies on far broader scales with concomitantly lower temporal resolution (e.g., Russell, 1993; Hirayama, 1997; Kriwet and Benton, 2004).

Stratigraphically correlated assemblages (SCAs) are temporally successive sampling bins defined by grouping several ammonite zones and/or calcareous nannofossil biozones, incorporating sequence stratigraphy, and, where possible, numerical ages (Fig. 1; see appendix for definitions). SCAs are designed to provide a broad framework for compiling late Cretaceous marine shelf and epicontental sea deposits. The fifteen SCAs employed here range from 1.2 to 3.0 myr each, with an average duration of approximately 2.3 myr (timescale from Gradstein et al., 2004). Although not uniform in duration, SCAs provide a practical framework for compiling and organizing marine fossils (both vertebrate and invertebrate) from far-ranging localities while retaining relatively high temporal resolution. While this study analyzes the mosasaur record, SCAs can be used as a binning system for virtually any set of late Cretaceous marine organisms.

\section{Database Construction}

The database used here consists of 1805 mosasaur specimens obtained from museum collections and published reports. Specimens are recorded from North and South America, Europe, Africa, Antarctica, Asia, Australia, and New Zealand, and each is identified to genus and confidently assigned to one of the fifteen SCAs (Table 1). The occurrences compiled in the database provide biostratigraphic ranges for twenty six mosasaur genera, and from this I reconstructed the standing richness of mosasaur genera per SCA during the Late Cretaceous (Fig. 2). The solid line represents the minimum standing generic richness per SCA, while the dashed line indicates maximum richness when taxa with unresolved occurrences in SCAs are incorporated.

\section{MOSASAUR RICHNESS THROUGH TIME}

Early mosasaurs retaining plesiopedal (land-capable) limb arrangement appear in the early Cenomanian and middle Turonian 


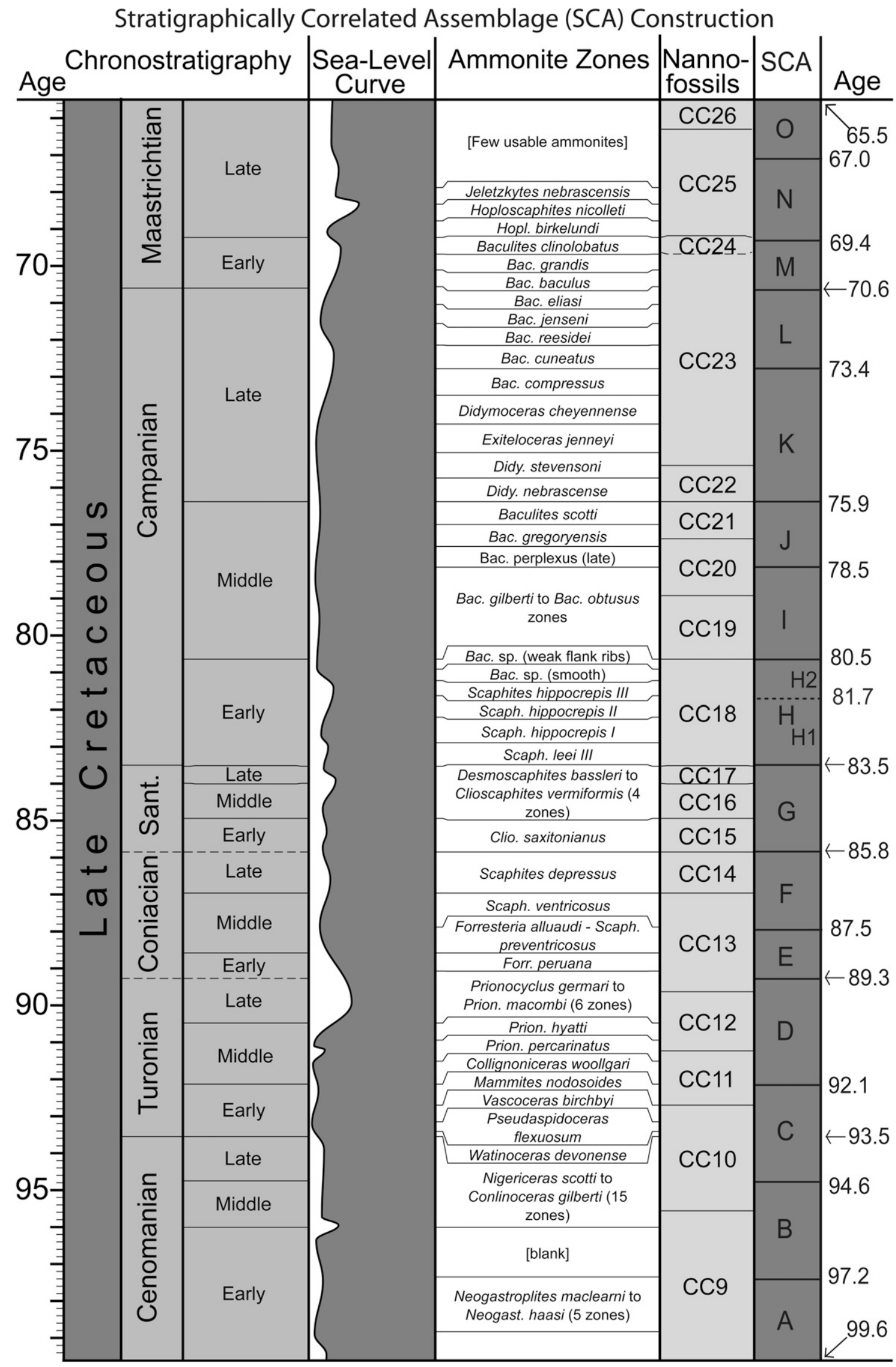

FIGURE 1. Graphical representation of SCAs; see appendix for definitions. SCA boundary ages given on right; ages with arrows denote currently accepted date for stage boundary. Late Cretaceous time scale, sea level curve, ammonite and nannofossil zones constructed using TS-Creator version 2.0. 
TABLE 1. Total number of mosasaur specimens recorded per SCA.

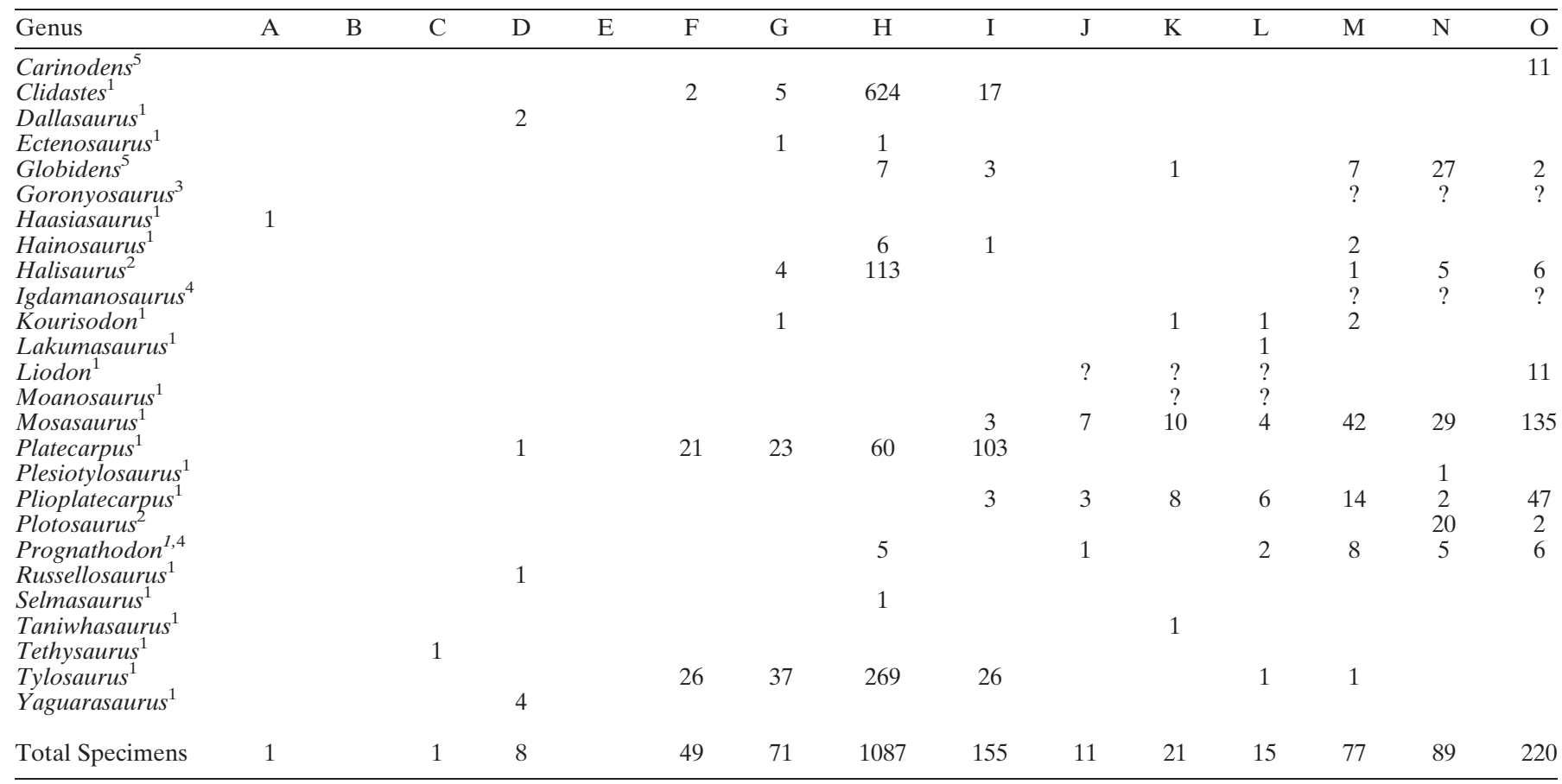

Superscripts indicate feeding guild assignment following Massare (1987, 1997; see text for discussion).

1, Cut; 2, Pierce II/General; 3, Smash; 4, Crunch; 5, Crush; ?, taxon with unresolved SCA assignment.

(Bardet et al., 2003; Bell and Polcyn, 2005; Polcyn and Bell 2005). Hydropedal (fully marine-adapted flipper) mosasaurs first appear in the middle Turonian (Lingham-Soliar 1994). Based on the standing richness curve (Fig. 2), hydropedal mosasaurs diversified steadily to the Campanian, experiencing peak richness levels during the early and late Campanian (SCAs H and L; Fig. 2). Mosasaur richness appears generally stable throughout the Campanian, and falls slightly during the Maastrichtian. This may indicate that mosasaur richness during the latest Maastrichtian (8 genera) was lower than the early or late Campanian (10 genera), or alternatively, it may be an artifact of uneven sampling intensity (e.g., Fastovsky et al., 2005).

\section{Analytical Techniques}

To determine if sampling artifacts are influencing the perception of mosasaur richness, I follow previous studies addressing vertebrate richness fluxes over time (e.g., Sheehan et al., 1991; Pearson et al., 2002; Fastovsky et al., 2004) in applying rarefaction to quantify richness through time. Rarefaction (Sanders, 1968; Hulbert, 1971; Simberloff, 1972) estimates the predicted number of taxa, $E(\hat{S} n)$, from a dataset of a number of individuals $(N)$, when only a portion of that dataset is sampled $(n \leq N)$, enabling comparison of datasets of unequal sizes. Tipper (1979) suggests that for $n / \mathrm{N}>0.1$, the rarefaction equation given by Hulbert (1971) is best selected:

$$
E\left(\hat{S}_{n}\right)=\sum_{i=1}^{s}\left[1-\frac{\left(\begin{array}{c}
N-N_{i} \\
n
\end{array}\right)}{\left(\begin{array}{c}
N \\
n
\end{array}\right)}\right]
$$

Variance is calculated independently using the equation of Heck et al. (1975):

$$
\begin{aligned}
\operatorname{var}\left(\hat{S}_{n}\right)= & \underset{n}{(N)^{-1}}\left[\sum_{i=1}^{s}\left(N-N_{i}\right)\left[1-\frac{\left(\begin{array}{c}
N-N_{i} \\
n
\end{array}\right)}{\left(\begin{array}{c}
N \\
n
\end{array}\right)}\right]\right. \\
& +2 \sum_{i=1}^{s-1} \sum_{j=i+1}^{s}\left[\left(N-N_{i}-N_{i}\right)-\frac{\left(\begin{array}{c}
\left.N-N_{i}\right)\left(N_{i}-N_{j}\right) \\
n
\end{array}\right.}{(N)}+\right]
\end{aligned}
$$

Standard deviation for the rarefied generic richness, $\sigma(\hat{\mathrm{S}} n)$, was calculated as the square root of the variance, $\operatorname{var}(\hat{\mathrm{S}} n)$. Mosasaur richness per SCA was calculated by rarefying selected samples to a particular value for standardized comparison. In this case, datasets with larger specimen counts were rarefied to a dataset with a smaller specimen count, and their generic richnesses compared. The analysis presented here, of surface and quarry-collected Late Cretaceous macrofossils from a single family of pelagic marine squamates satisfies the criteria of Tipper (1979) for the application of rarefaction to fossil databases.

Seven SCAs: F, G, H, I, M, N, and O, were selected for comparison on the basis of adequate sample size $(n \geq 30$ per SCA; Table 1). The data from these SCAs were rarefied to $n=$ 49 , the smallest number of specimens among the SCAs (SCA-F). For $n \geq 30,95 \%$ confidence intervals are calculated as $\pm 1.96 \sigma$ from that sample's rarefied generic richness.

\section{Results}

Results of the rarefaction analysis are presented in Table 2 and Figure 3. All rarefied SCA richness values and confidence intervals are compared to those of SCA-F. All SCAs and their $95 \%$ confidence intervals lie above the richness of SCA-F (three genera) when rarefied to $n=49$. Utilizing minimum numbers of 


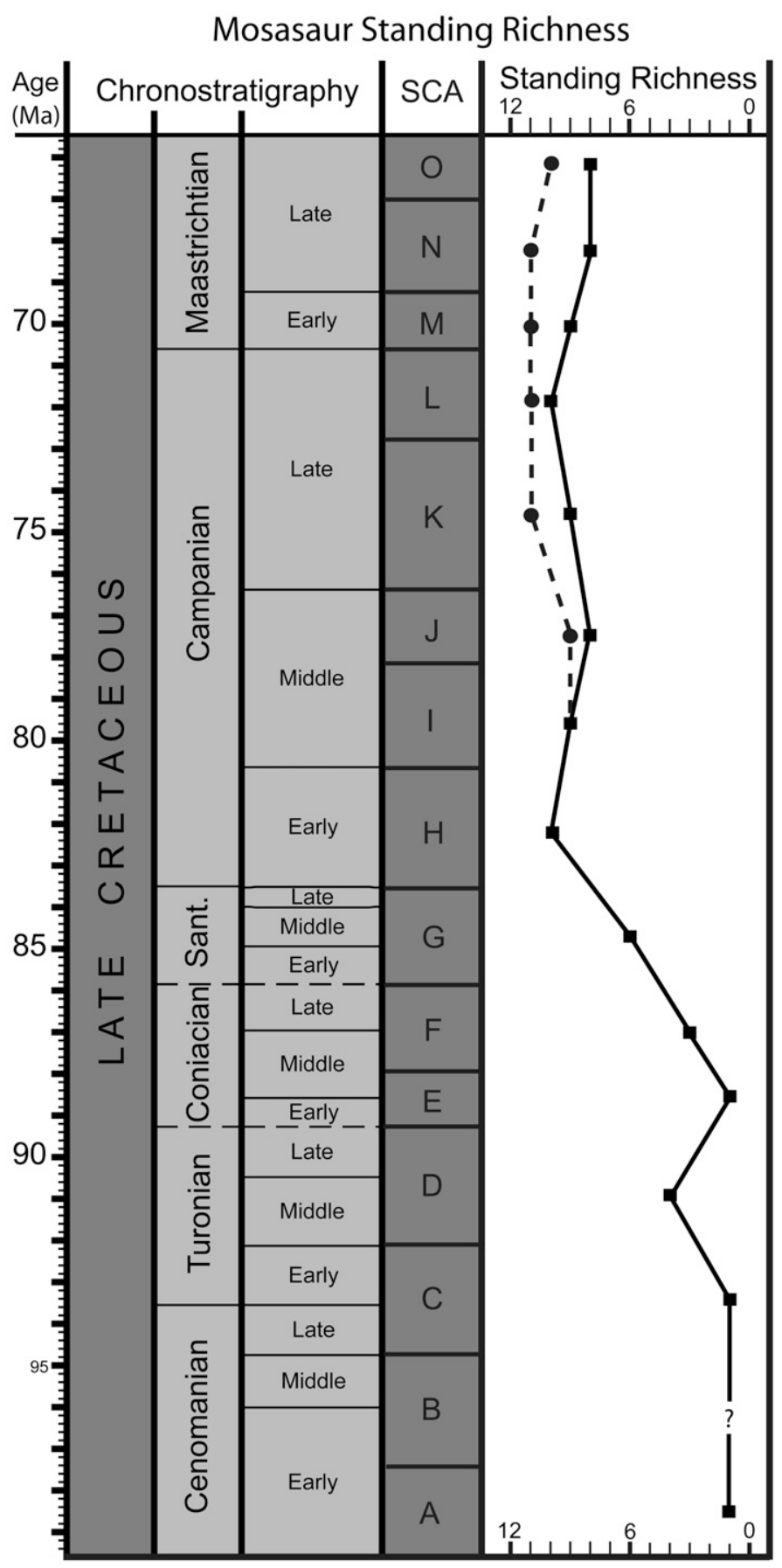

FIGURE 2. Standing richness of mosasaur genera per SCA. Solid line and squares indicate minimum richness per SCA. Dashed line and circles indicate the upper limit of mosasaur generic richness in instances where the precise biostratigraphies of certain genera are not fully resolved. Late Cretaceous time scale constructed using TS-Creator version 2.0. individuals (MNI) for statistical analysis yielded similar results (see Ross, 2006).

\section{Discussion}

The low richness value of SCA-F in comparison to all other rarefied SCA values (Fig. 3) indicates that despite differences in sample size, the middle- and late Coniacian mosasaur fauna was significantly less rich than those from any subsequent SCA. Thus the apparent trajectory (Fig. 2) of the hydropedal mosasaur radiation during the Coniacian and Santonian is indeed real. Given the first appearance of Platecarpus (=Angolasaurus) in the late Turonian (Lingham-Soliar 1994) and high mosasaur richness in the early Campanian (Table 1), this initial radiation of hydropedal mosasaurs occurred over approximately 7 myr (using the timescale of Gradstein et al., 2004).

However, the above analysis could not determine among the competing hypotheses for mosasaur richness during the Campanian and Maastrichtian (above). To address this, I rarefied the Campanian and Maastrichtian SCAs to $n=77$, the lowest sample size among viable Campanian and Maastrichtian SCAs. These data are presented in Table 2 and Figure 4. Again, using MNI for statistical analysis yielded similar results (Ross, 2006).

When rarefied, both of the confidence intervals for the Campanian SCAs available for analysis ( $\mathrm{H}$ and $\mathrm{I}$ ) fall below the richness of SCA-M. Thus the taxonomically rich mosasaur communities in the early Campanian are actually statistically significantly less rich than those in the early Maastrichtian. During the Maastrichtian, the rarefied richness level of latest Maastrichtian SCA-O cannot be distinguished from SCA-M, while middle Maastrichtian SCA-N is statistically significantly lower than SCA-M. This may indicate that richness levels in the Maastrichtian were fluctuating, though the overall trend appears stable. Likely affecting this picture are taxa known to exist in the Maastrichtian which cannot be confidently assigned to one or more SCAs (Table 1).

\section{RICHNESS LEVELS AND MORPHOLOGICAL DIVERSITY}

Given the above, it is possible to trace the morphological trends within the context of the first appearance of plesiopedal mosasaurs, followed by the appearance and continued radiation of hydropedal mosasaurs during the late Cretaceous. Throughout their history, mosasaurs followed two morphological trajectories: increasing adaptation to their marine environment and increasing dental morphological complexity. Here I will examine the latter. Massare (1987; 1997, p. 406-407) defined six feeding guilds for Mesozoic marine reptiles based upon tooth morphology:

Cut-Pointed, robust cone with two or more sharp longitudinal carinae or ridges, which can be serrated.

Pierce II/General-Pointed, somewhat slender, curved tooth of moderate length. Two carinae or fine longitudinal ridges are often present.

Pierce I-Very slender, sharply pointed, long, delicate tooth which can be smooth or have fine longitudinal ridges.

Smash-Small, straight or slightly curved tooth with a rounded but acute apex.

TABLE 2. Rarefaction of mosasaur richness per SCA, rarefied to $n=49$ and $n=77$.

\begin{tabular}{|c|c|c|c|c|c|c|c|}
\hline & SCA-F & SCA-G & SCA-H & SCA-I & SCA-M & SCA-N & SCA-O \\
\hline \# Individuals, $N$ & 49 & 71 & 1087 & 155 & 77 & 89 & 220 \\
\hline$E(\hat{S} n)$ for $n=49$ & 3 & 5.37 & 4.75 & 5.35 & 7.01 & 6.32 & 6.24 \\
\hline$\sigma(\hat{S} n)$ for $n=49$ & $(-)$ & 0.66 & 0.82 & 0.92 & 0.81 & 0.66 & 0.94 \\
\hline$\sigma(\hat{S} n)$ for $n=77$ & $\mathrm{x}$ & $\mathrm{x}$ & 0.90 & 0.76 & $(-)$ & 0.36 & 0.79 \\
\hline
\end{tabular}




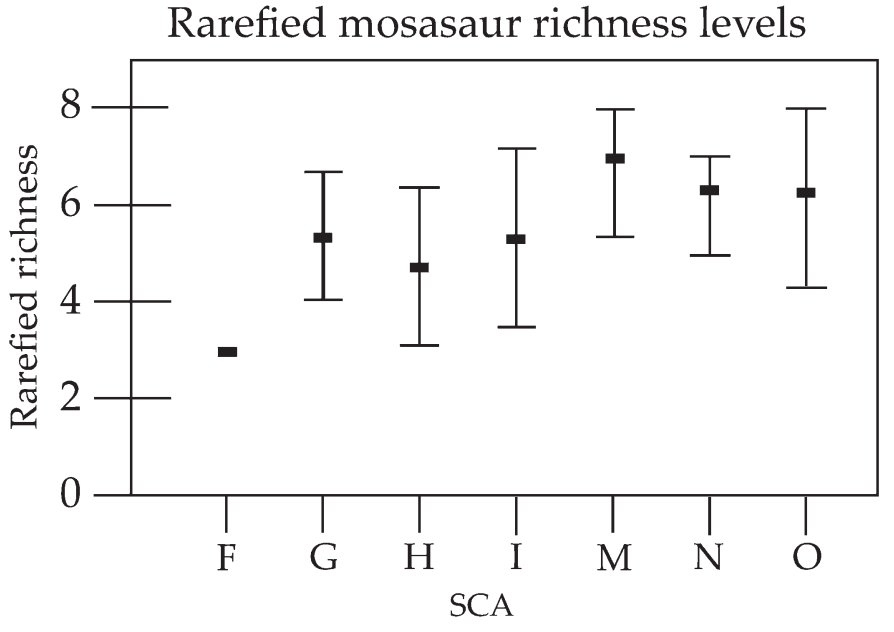

FIGURE 3. Plot of mosasaur richness among SCAs F, G, H, I, M, N, and $O$. Data are rarefied to $n=49$ (solid rectangles) and $95 \%$ confidence intervals are plotted (vertical bars).

Crush-Small, robust, straight or slightly curved tooth with a blunt apex.

Crunch-Very blunt, bulbous or peg-like.

She then $(1987,1997)$ assigned mosasaur taxa to at most three guilds (cut, crush, and possibly pierce II/general). Re-examination of mosasaur dental morphology expands the variety of guilds exploited to include "cut," "pierce II/general," "smash," "crush," and "crunch," and illuminates trends in the acquisition of novel dental morphologies (Fig. 5). Mosasaur genera were assigned to feeding guilds (Table 1), and I tabulated the number of genera per feeding guild per SCA (Table 3 ). The relative abundances of guilds from selected SCAs are presented in Figure 6.

\section{Discussion}

Novel dental morphologies, inferred to reflect differences in feeding adaptations, appear sporadically among mosasaurs during the Late Cretaceous (Table 3). The earliest, plesiopedal mosasaurs from the Cenomanian and Turonian (SCAs A through D) were small near-shore predators with 'cut' guild

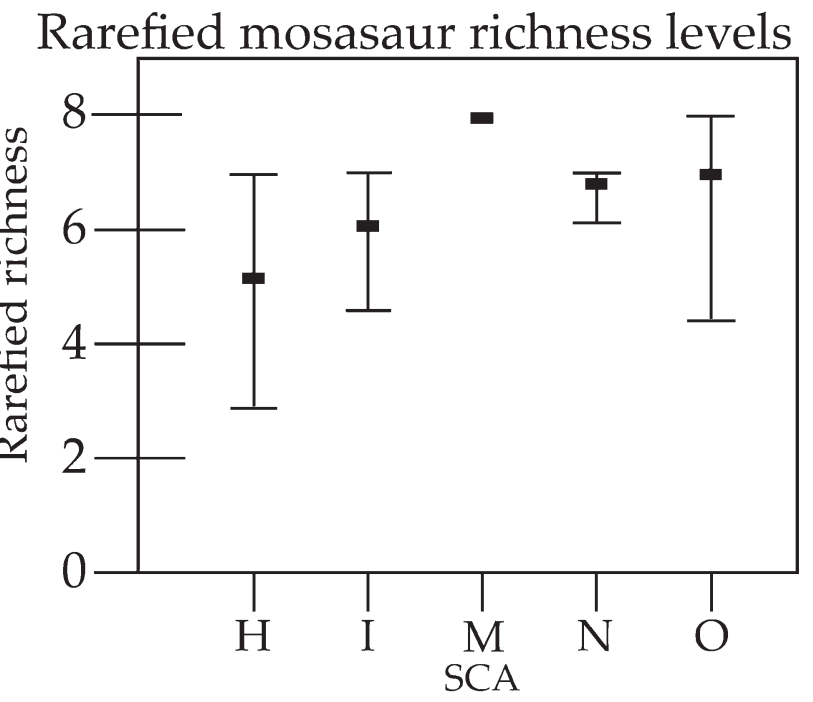

FIGURE 4. Plot of mosasaur richness among SCAs H, I, M, N, and O. Data are rarefied to $n=77$ (solid rectangles) and $95 \%$ confidence intervals are plotted (vertical bars).
Simplified phylogeny of the Mosasauridae depicting tooth morphologies

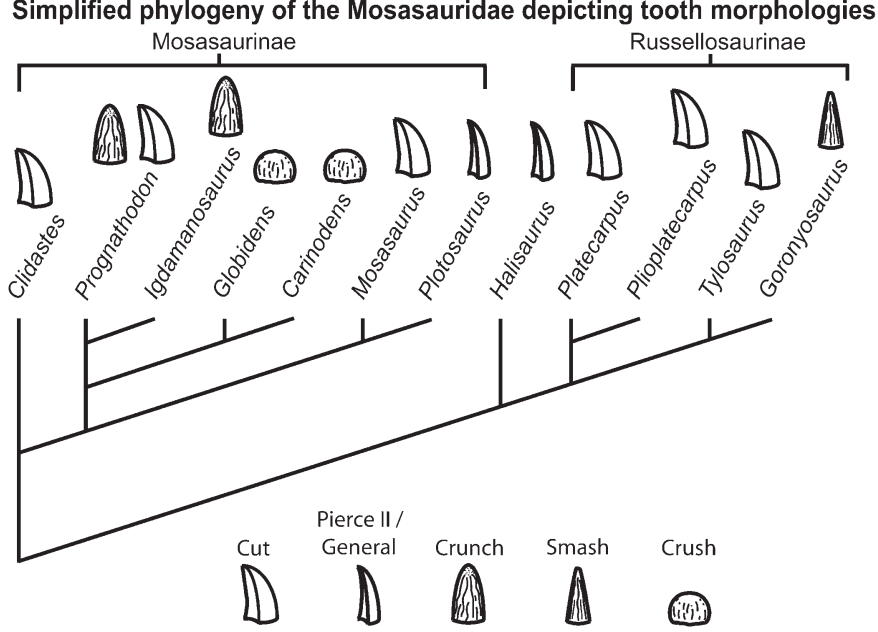

FIGURE 5. Tooth morphology guilds (from Massare, 1987, 1997) assigned to a simplified phylogeny of the Mosasauridae. Phylogeny based on Bell and Polcyn (2005), Lingham- Soliar (1988), and Schulp et al. (2004). The genus Prognathodon includes species assigned to both the "cut" and "crunch" guilds.

tooth morphologies (Fig. 6, Table 3). Early hydropedal mosasaurs from the Turonian and Coniacian (SCAs D through F), including Clidastes, Platecarpus, and Tylosaurus, were generalist ambush predators also within the "cut" guild. They possess the dominant dental morphology among all mosasaurs, and differences in prey among these taxa are thought to have been related to body size: the $>10 \mathrm{~m}$ Tylosaurus is known to have consumed fish, sharks, and swimming birds, as well the $\sim 4 \mathrm{~m}$ Clidastes (Martin and Bjork, 1987). For nearly 14 myr, all known mosasaurs retained the "cut" guild tooth morphology (Fig. 6). The first appearance of Halisaurus in the middle Santonian introduces the first novel tooth morphology among mosasaurs ("pierce II/general"; Fig. 6, SCAs A-G).

Based on dental morphologies, throughout the bulk of the Campanian (SCAs H-K), generalist "cut" guild members comprised approximately $80 \%$ of the mosasaur genera at any given time, while "pierce II/general" and "crunch" guilds are sparsely represented (Table 3, Fig. 6). The first decline (73\%; Fig. 6) in "cut" guild mosasaurs during latest Campanian SCA-L coincided with the first appearance of the "crunch" guild mosasaurs. These changing percentages presage the more significant changes in mosasaur predatory behavior in the Maastrichtian.

During the Maastrichtian, both the percentage and raw number of "cut" guild genera plummets, mosasaur feeding behavior becomes more evenly distributed among guilds (Table 3, Fig. 6). Far from their predatory dominance during the Campanian, "cut" guild members are reduced to $37 \%$ of genera by the close of the Maastrichtian (SCA-O). During this same time, mosasaurs which preyed upon shelled organisms ("crunch" and "crush" guilds) become as taxonomically rich as generalists.

The change in mosasaur predatory behavior during the Maastrichtian was complex, being driven by at least three factors. First, as noted above, during at least part of the Maastrichtian, mosasaur richness levels were higher than during the early Campanian. However, and most interesting, Maastrichtian richness levels also appear generally stable (see above), so the largest shifts in tooth guild acquisition and distribution are occurring within the context of stable richness. Second, cut-guild russelosaurines (Bell and Polcyn, 2005; Fig. 5) decline precipitously. Third, expansion of the mosasaurines (Bell and Polcyn, 2005; Fig. 5) fuels rapid tooth guild diversification (Fig. 6). Here I will focus on the last two points. 
TABLE 3. Number of mosasaur genera per tooth guild per SCA.

\begin{tabular}{|c|c|c|c|c|c|c|c|c|c|c|c|c|c|c|c|}
\hline Tooth Guilds & $\mathrm{A}$ & $\mathrm{B}$ & $\mathrm{C}$ & $\mathrm{D}$ & $E$ & $\mathrm{~F}$ & $\mathrm{G}$ & $\mathrm{H}$ & I & $\mathrm{J}$ & $\mathrm{K}$ & $\mathrm{L}$ & $\mathrm{M}$ & $\mathrm{N}$ & $\overline{\mathrm{O}}$ \\
\hline $\begin{array}{l}\text { Cut } \\
\text { Pierce I }\end{array}$ & 1 & - & 1 & 4 & 1 & 3 & 5 & 8 & 8 & $6(7)$ & $7(9)$ & $7(8)$ & 7 & $4(5)$ & $\overline{4}$ \\
\hline $\begin{array}{l}\text { Pierce II/General } \\
\text { Smash }\end{array}$ & & & & & & & 1 & 1 & 1 & 1 & 1 & 1 & $\begin{array}{c}1 \\
(1)\end{array}$ & $\begin{array}{c}2 \\
(1)\end{array}$ & $\begin{array}{c}2 \\
(1)\end{array}$ \\
\hline $\begin{array}{l}\text { Crunch } \\
\text { Crush }\end{array}$ & & & & & & & & 1 & 1 & 1 & 1 & $\begin{array}{l}1 \\
1\end{array}$ & $\begin{array}{c}1(2) \\
1\end{array}$ & $\begin{array}{c}1(2) \\
2\end{array}$ & $\begin{array}{c}1(2) \\
2\end{array}$ \\
\hline
\end{tabular}

Numbers in parentheses represent highest possible number of genera per guild when stratigraphically unresolved taxa are considered. Feeding guilds from Massare $(1987,1997)$.

With the exception of the Maastrichtian "smash" guild genus Goronyosaurus, all russelosaurines fall within the "cut" guild (Fig. 5; Table 1). After the last appearances of Tylosaurus and Hainosaurus in the early Maastrichtian (SCA-M), russellosaurines were reduced to no more than two genera. Mosasaurines, however, displayed considerable morphological differentiation early in the clade, with the first appearance of the "crunch" guild Globidens in the early Campanian (Russell, 1975). Even among the plesiomorphic "cut" guild mosasaurines, such as Clidastes, Kourisodon, and Prognathodon, there are markedly different tooth morphologies (see Russell, 1967; Nicholls and Meckert, 2002). These basal morphologies served as platforms for the acquisition of derived "pierce II/general," "crunch," and "crush" guilds during the latest Campanian and Maastrichtian. Moreover, the numerical dominance of mosasaurine 'cut' guild generalists such as Mosasaurus compared to the russellosaurine Plioplacearpus (Table 1) indicate that intra-clade generalist competition was dominated by mosasaurines.

Relative abundance (\# genera) of mosasaur feeding guilds
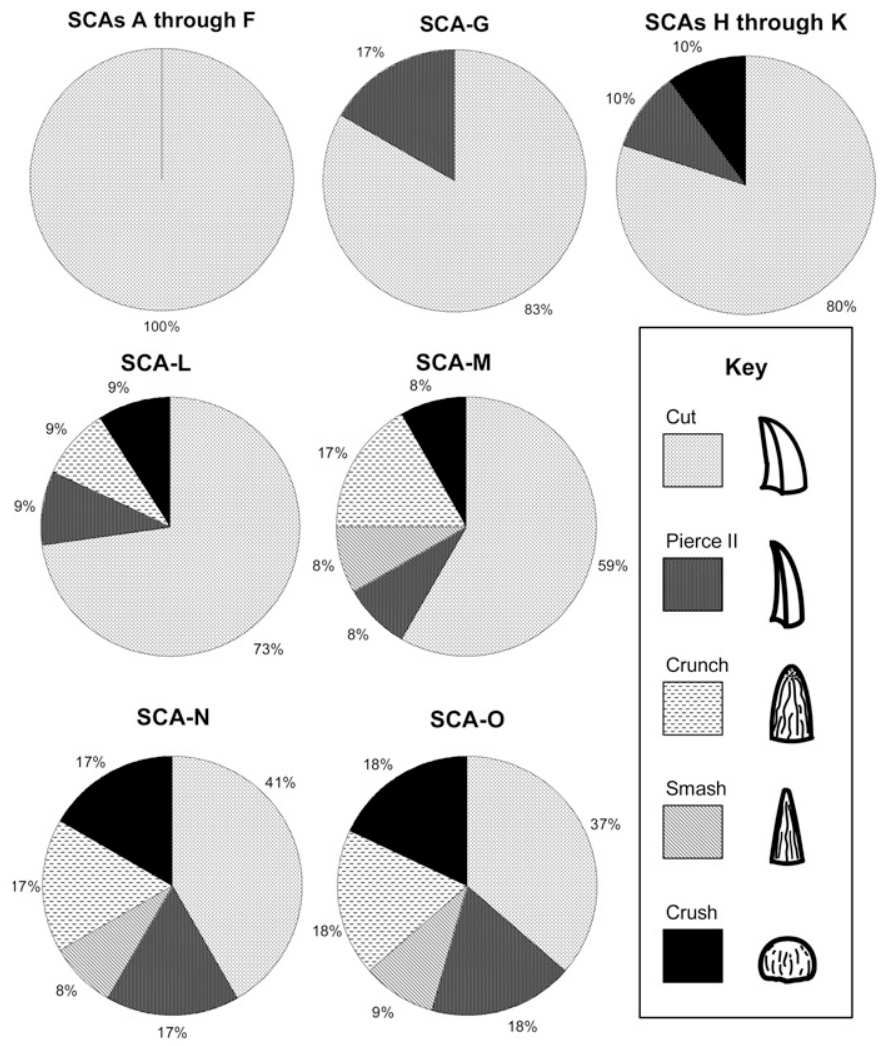

FIGURE 6. Relative abundance plots of mosasaur feeding guilds for all SCAs in the late Cretaceous. Maximum numbers of genera per tooth guild (Table 1) are plotted. Tooth guilds drawn after Massare (1987). Minimum counts produce slight differences but display the same trends.
By the latest Maastrichtian (SCA-O), mosasaurs had developed tooth morphologies representing five of Massare's six feeding guilds, and also displayed considerable intra-guild diversity, particularly among mosasaurines. Mosasaurs apparently converged on similar tooth morphologies seen in extinct groups. The highly derived mosasaurine Plotosaurus, a "pierce II/general" guild member and probable pursuit predator, converged on features seen in early ichthyosaurs (Camp, 1942; Lindgren et al., 2007). Likewise, the tooth morphology of "crunch" guild members Prognathodon and Igdamanosaurus converged on the ammonite-consuming ichthyosaurs (Lingham-Soliar, 1988; Christiansen and Bonde, 2002; Massare, 1987, 1997).

Other mosasaurs competed directly with other taxa already occupying certain feeding guilds. Plesiomorphic "cut" guild members and the "smash" guild Goronyosaurus may have competed for the prey of other large predatory reptiles such as plesiosaurs and crocodilians, respectively (see Lingham-Soliar, 2002, concerning the latter). The success of the "cut" guild mosasaurs may be due to advantages in ambush-style predatory behavior during much of the Late Cretaceous (Massare, 1997). Regardless of whether they opportunistically exploited novel feeding strategies or competed directly against established groups, by the close of the Maastrichtian mosasaurs established themselves as the top predators in every ecological arena in which they competed.

\section{CONCLUSIONS}

Throughout their history, mosasaurs developed far greater diversity of predatory behavior among fewer taxa and over a shorter time than any other single group of Mesozoic marine reptiles, perhaps even among all marine vertebrates. By the time of their extinction, mosasaurs had undergone a significant radiation early in their history, and maintained high generic richness levels throughout the Maastrichtian. That their ultimate extinction event coincides with the zenith of their morphological and ecological diversity, including large and small generalist predators, pursuit-style piscivores, mollusc-crushers, cephalopodcrunchers, and crocodiliform estuary dwellers, only serves to cast their demise into greater relief.

\section{ACKNOWLEDGMENTS}

Many thanks to G. Bishop, D. Brinkman, J. Bolt, M. BrettSurmann, T. Culver, J. Ebersol, M. Everhart, W. Gallagher, N. Gilmore, P. Holroyd, J. Ingle, R. Johnson, D. King, S. MacLeod, L. Martin, C. Mehling, D. Miao, D. Parris, A. Rinsburg, A. Schulp, and G. Taguchi, who provided great assistance in researching collections, and for helpful discussions on local stratigraphy and collections history. I thank G. Bell for discussions on mosasaurs, and H. Cappetta for aid in refining mosasaur records from Morocco. I am indebted to D. E. Fastovsky and three anonymous reviewers for comments and critiques of earlier drafts of this manuscript. The Department of Geosciences at the University of Rhode Island provided much of the support and facilities, and the Geological Society of America provided partial support used in the completion of this project. 


\section{LITERATURE CITED}

Bardet, N., X. P. Suberbiola, and N.-E. Jalil. 2003. A new mosasauroid (Squamata) from the Late Cretaceous (Turonian) of Morocco, Comptes Rendus Palevol 2:607-616.

Bell, G. L., Jr., and M. Polcyn. 2005. Dallasaurus turneri, a new primitive mosasauroid from the Middle Turonian of Texas and comments on the phylogeny of Mosasauridae (Squamata). Netherlands Journal of Geosciences 84:177-194.

Camp, C. L. 1942. California Mosasaurs. University of California Press, Berkeley, California, $67 \mathrm{pp}$.

Christiansen, P., and N. Bonde. 2002. A new species of gigantic mosasaur from the late Cretaceous of Israel. Journal of Vertebrate Paleontology 22:629-644.

Cobban, W. A. 1993. Diversity and distribution of Late Cretaceous Ammonites, Western Interior, United States; pp. 435-451 in W. G. E. Caldwell and E. G. Kauffman (eds.), Evolution of the Western Interior Basin. Canadian Association of GeologistsSpecial Paper 39.

Cobban, W. A., E. A. Merewether, T. D. Fouch, and J. D. Obradovich. 1994. Some Cretaceous shorelines in the Western Interior of the United States; pp. 393-425 in M. V. Caputo, J. A. Peterson, and K. J. Franczyk (eds.), Mesozoic Systems of the Rocky Mountain Region. USA.

Fastovsky, D. E., Y. Huang, J. Hsu, J. Martin-McNaughton, P. M. Sheehan, and D. B. Weishampel. 2004. Shape of Mesozoic dinosaur richness. Geology 32:877-880.

Fastovsky, D. E., Y. Huang, J. Hsu, J. Martin-McNaughton, P. M. Sheehan, and D. B. Weishampel. 2005. Shape of Mesozoic dinosaur richness, Comment and Reply. Geology (online) DOI 10.1130/0091-7613(2005) $31<\mathrm{e} 75: \mathrm{R}>2.0 . \mathrm{CO} ; 2$

Gradstein, F. M., J. G. Ogg, and A. G. Smith. 2004. A Geologic Time Scale 2004. Cambridge University Press, Cambridge, United Kingdom, $589 \mathrm{pp}$

Haq, B., J. Hardenbol, and P. Vail. 1987. Chronology of fluctuating sea levels since the Triassic. Science 235:1156-1167.

Heck, K. L. J., G. Van Belle, and D. Simberloff. 1975. Explicit calculation of rarefaction diversity measurement and the determination of sufficient sample size. Ecology 56:1459-1461.

Hirayama, R. 1997. Distribution and diversity of Cretaceous chelonioids; pp. 225-241 in J. M. Calloway and E. L. Nicholls (eds.), Ancient Marine Reptiles. San Diego: Academic Press.

Hulbert, S. H. 1971. The non-concept of species diversity: a critique and alternative parameters. Ecology 59:577-586.

Kennedy, W. J., N. H. Landman, W. K. Christensen, W. A. Cobban, and J. M. Hancock. 1998. Marine connections in North America during the late Maastrichtian: Palaeogeographic and palaeobiogeographic significance of the Jeletzkytes nebrascensis Zone cephalopod fauna from the Elk Butte Member of the Pierre Shale, SE South Dakota and NE Nebraska. Cretaceous Research 19:745-775.

Kriwet, J., and M. J. Benton. 2004. Neoselachian (Chondrichthyes, Elasmobranchii) diversity across the Cretaceous-Tertiary Boundary. Palaeogeography, Palaeoclimatology, Palaeoecology. 214:181-194.

Landman, N. H., R. O. Johnson, and L. E. Edwards. 2004a. Cephalopods from the Cretaceous-Tertiary boundary interval in Atlantic Coastal Plain, with a description of the highest ammonite zones in North America. Part 1. Maryland and North Carolina: American Museum Novitates 3454, $64 \mathrm{pp}$.

Landman, N. H., R. O. Johnson, and L. E. Edwards. 2004b. Cephalopods from the Cretaceous/Tertiary boundary interval on the Atlantic Coastal Plain, with a description of the highest ammonite zones in North America. Part 2. Northeastern Monmouth County, New Jersey. Bulletin of the American Museum of Natural History 287:107 pp.

Lindgren, J., J. W. M. Jagt, and M. W. Caldwell. 2007. A fishy mosasaur: the axial skeleton of Plotosaurus (Reptilia, Squamata) reassessed. Lethaia 40:153-160.

Lingham-Soliar, T. 1988. The mosasaur Goronyosaurus from the upper Cretaceous of Sokoto State, Nigeria. Paleontology 31:747-762.

Lingham-Soliar, T. 1994. The mosasaur "Angolasaurus " bocagei (Reptilia: Mosasauridae) from the Turonian of Angola re-interpreted as the earliest member of the genus Platecarpus. Paläont. Z. 68:267-282.

Lingham-Soliar, T. 2002. First occurrence of premaxillary caniniform teeth in the Varanoidea: Presence in the extinct mosasaur Goronyosaurus (Squamata: Mosasauridae) and its functional and paleoecological implications. Lethaia 35:187-190.
Martin, J. E. M., and P. R. Bjork. 1987. Gastric residues associated with a mosasaur from the Late Cretaceous (Campanian) Pierre Shale in South Dakota. Dakoterra 3:68-72.

Massare, J. A. 1987. Tooth morphology and prey preference of Mesozoic marine reptiles. Journal of Vertebrate Paleontology 7:121-137.

Massare, J. A. 1997. Part VI: Faunas, behavior and evolution-introduction; pp. 401-421 in J. M. Callaway and E. L. Nicholls (eds.), Ancient Marine Reptiles. Academic Press, San Diego, California.

Miller, K. G., P. J. Sugarman, J. V. Browning, M. A. Kominz, J. C. Hernandez, R. K. Olsson, and J. D. Wright. 2003. Late Cretaceous chronology of large, rapid sea-level changes: Glacioeustasy during the greenhouse world. Geology 31:585-588.

Mulder, E. W. A. 2003. On latest Cretaceous tetrapods from the Maastrichtian type area. Publicaties van het Natuurhistorisch Genootshap in Limburg, Reeks XLIV, aflevering, Natuurpublicaties Limburg, Maastricht, $188 \mathrm{pp}$.

Mulder, E. W. A., J. W. M. Jagt, M. M. M. Kuypers, H. H. G. Peeters, and P. Rompen. 1998. Preliminary observations on the stratigraphic distribution of late Cretaceous marine and terrestrial reptiles from the Maastricht area (SE Netherlands, NE Belgium). Oryctos 1:55-64.

Nicholls, E., and D. Meckert. 2002. Marine reptiles from the Nanaimo Group (Upper Cretaceous) of Vancouver Island. Canadian Journal of Earth Sciences 39:1591-1603.

Obradovich, J. D. 1993. A Cretaceous time scale; pp. 379-396 in W. G. E. Caldwell and E. G. Kauffman (eds.), Evolution of the Western Interior basin. Geological Association of CanadaSpecial Paper 39

Pearson, D. A., T. Schaefer, K. R. Johnson, D. J. Nichols, and J. P. Hunter. 2002. Vertebrate biostratigraphy of the Hell Creek Formation in southwestern North Dakota and northwest South Dakota; pp. 145-167 in J. H. Hartman, K. R. Johnson, and D. J. Nichols (eds.), The Hell Creek Formation of the northern Great Plains: an integrated continental record of the end of the Cretaceous. Geological Society of America Special Paper 361, Boulder, Colorado.

Perch-Nielsen, K. 1985. Mesozoic calcareous nannofossils; pp. 329-426 in H. M. Bolli, J. B. Saunders, and K. Perch-Nielsen (eds.), Plankton Stratigraphy. Cambridge University Press, Cambridge, England.

Polcyn, M., and G. L. Bell. 2005. Russellosaurus coheni n. gen., n. sp., a 92 million-year old mosasaur from Texas (USA), and the definition of the parafamily Russellosaurina. Netherlands Journal of Geosciences 84:321-333.

Ross, M. 2006. Richness trends of mosasaurs (Diapsida, Squamata) during the late Cretaceous. Ph.D. dissertation University of Rhode Island, $197 \mathrm{pp}$.

Russell, D. A. 1967. Systematics and morphology of American mosasaurs. Peabody Museum of Natural History Bulletin 23. Yale University, New HavenConnecticut 237 pp.

Russell, D. A. 1993. Vertebrates in the Cretaceous Western Interior Sea; pp. 665-680 in W. G. E. Caldwell and E. G. Kauffman (eds.), Evolution of the Western Interior Basin. Geological Association of CanadaSpecial Paper 39.

Sanders, H. L. 1968. Marine benthic diversity: A comparative study. Biometrics 25:517-535.

Schulp, A. S., J. W. M. Jagt, and F. Fonken. 2004. New material of the mosasaur Carinodens belgicus from the Upper Cretaceous of the Netherlands. Journal of Vertebrate Paleontology 24:744-747.

Sheehan, P. M., D. E. Fastovsky, R. G. Hoffman, C. B. Berghaus, and D. L. Gabriel. 1991. Sudden extinction of the dinosaurs: latest Cretaceous, upper Great Plains, USA. Science 254:835-839.

Sheldon, M. A. 1996. Stratigraphic distribution of mosasaurs in the Niobrara Formation of Kansas. Paludicola 1:21-31.

Simberloff, D. S. 1972. Properties of the rarefaction diversity measurement. American Naturalist 106:414-418.

Sissingh, W. 1977. Biostratigraphy of Cretaceous calcareous nannoplankton. Geologie en Mijnbouw 56(1):37-65.

Tipper, J. C. 1979. Rarefaction and rarefiction-the use and abuse of a method in paleoecology. Paleobiology 5:423-434.

TS-Creator visualization of enhanced Geologic Time Scale 2004 database (Version 2.0; 2006). J. Ogg (database coordinator) and A. Lugowski (software developer). http://www.stratigraphy.org and http://www.chronos.org.

Submitted November 15, 2006; accepted August 14, 2008. 
APPENDIX: SCA DEFINITIONS Each SCA is defined on the basis of ammonites and calcareous nannofossil biozones, eustatic sea level cycles, and numerical ages. Unless otherwise indicated, the ammonite zones follow Cobban's (1993) and the Cobban et al.'s (1994) zonation from deposits of the Western Interior of North America. Calcareous nannoplankton zones are included according to the formulation of Sissingh (1977) and Perch-Nielsen (1985). The third-order eustatic cycles of Haq et al. (1987) are employed to designate global sea level sequences, and aid in refining the timeframe for lithologic units of uncertain age. Numerical ages for the upper and lower boundaries of each SCA are discussed to the resolution available, according to the current time scale for the late Cretaceous (Gradstein et al., 2004). The SCAs and their respective biostratigraphic and sequence-stratigraphic criteria are illustrated in Figure 1.

SCA-A spans the early Cenomanian, from ammonite zones Neogastroplites haasi to $N$. maclearni. It includes calcareous nannoplankton subzone CC9a and lower subzone CC9b, and third-order cycle UZA 2.3 . The base of the Cenomanian (and the Late Cretaceous) is currently placed at $99.6 \pm 0.9 \mathrm{Ma}$ (Gradstein et al., 2004). Obradovich (1993) reported the age of the Clay Spur bentonite (above the N. maclearni zone) in the Mowry Shale as $97.2 \pm 0.7 \mathrm{Ma}$. The duration of SCA-A is approximately 2.3 myr.

SCA-B spans the late early Cenomanian through the middle Cenomanian, from ammonite zones Conlinoceras tarrantense to Plesiacanthocera wyomingense. It includes the third-order cycled UZA2.4 and the upper portion of nannoplankton subzone CC9b. The Clay Spur bentonite at top of the Mowry Shale in Wyoming provides an age of $97.2 \pm 0.7 \mathrm{Ma}$ (Obradovich, 1993) for the base of SCA (B). A bentonite from the Dunveganoceras pondi zone (which overlies the $P$. wyomingense zone) of the Frontier Fm. in Wyoming is dated at $94.6 \pm 0.6 \mathrm{Ma}$ (Obradovich, 1993). This provides an upper limit for the age of SCA (B), and a maximum duration of approximately $2.4 \mathrm{myr}$ for this SCA.

SCA-C spans the late Cenomanian through early Turonian. It includes sedimentary units deposited during the highest eustatic sea levels of the Cretaceous (UZA2.5; Haq et al., 1987). It includes the late Cenomanian ammonite zone of Dunveganoceras pondi to the early Turonian Mammites nodosoides, and nannofossil zones $\mathrm{CC} 10$ and lower CC11. A bentonite from the Dunveganoceras pondi zone in the Frontier Fm. of Wyoming is dated at $94.6 \pm 0.6 \mathrm{Ma}$ (Obradovich, 1993), and provides a date for the base of SCA-C. A pronounced drop in sea level marking the UZA 2.5/2.6 boundary defines the top of SCA-C. Based upon ${ }^{40} \mathrm{Ar} /{ }^{39} \mathrm{Ar}$ dates (Obradovich, 1993), this boundary must be younger than $93.3 \mathrm{Ma}$ (Neocardioceras juddii zone; latest Cenomanian) and older than $90.5 \mathrm{Ma}$ (Prionocyclus hyatti zone; middle Turonian). Based upon Sr-isotope curves from the Raritan Fm. in New Jersey, the age of top of the Bass River III sequence is $92.8-92.1 \pm 1.0 \mathrm{Ma}$ (Miller et al., 2003). SCA-C is likely no more than 2.5 myr in duration.

SCA-D spans the middle to late Turonian, and includes ammonite zones Collignoniceras woollgari through Prionocyclus germari as well as the upper portion of nannofossil zone $\mathrm{CC} 11$, all of $\mathrm{CC12}$, and perhaps the base of CC13. It includes third-order eustatic cycles UZA2.6, UZA2.7, and the base of UZA3.1. The base of SCA (D) is approximately equivalent to the top of the Bass River III sequence in New Jersey, from 92.8$92.1 \pm 1.0$ Ma (Miller et al., 2003). The current age for the Turonian/ Coniacian boundary is $89.3 \pm 1.0 \mathrm{Ma}$ (Gradstein et al., 2004), making the duration of SCA-D between 1.8 and 2.5 myr.

SCA-E spans the early- to early-middle Coniacian, and includes the ammonite zones of Forresteria peruana and $F$. alluaudi. It includes nannofossil zone $\mathrm{CC} 13$ and much of the third-order cycle UZA3.1. The base of the Coniacian is currently dated at $89.3 \pm 1.0 \mathrm{Ma}$ (Gradstein et al., 2004), and a bentonite from the Marias River Shale, Montana, in the Scaphites preventricosus zone (correlative to the $F$. alluaudi zone) is dated at $88.3 \pm 0.6 \mathrm{Ma}$ (Obradovich, 1993). The top of UZA3.1 is dated at $87.5 \pm 1.0 \mathrm{Ma}$ based, on Sr-isotope curves (Miller et al., 2003). The duration of SCA (E) is approximately $1.8 \mathrm{myr}$.

SCA-F spans the early-middle to late Coniacian, and includes the ammonite zones of Schaphites ventricosus and $S$. depressus, nannofossil zone CC14 and the third-order cycle UZA3.2. The base of UZA3.2 is placed at $87.5 \pm 1.0 \mathrm{Ma}$ (Miller et al., 2003), and the Coniacian/Santonian boundary is currently assigned a date of $85.8 \pm 0.7 \mathrm{Ma}$ (Gradstein et al., 2004). The duration of SCA (F) is approximately 1.7 myr.

SCA-G spans the Santonian stage. The duration of the Santonian, 2.3 myr; from $85.8 \pm 0.7 \mathrm{Ma}$ to $83.5 \pm 0.7 \mathrm{Ma}$ (Gradstein et al., 2004). It includes the ammonite zones Clioscaphites saxitonianus through Desmoscaphites bassieri and nannofossil zones CC15 through CC17. It includes sea-level cycle UZA3.3, and nearly all of UZA3.4
SCA-H is early Campanian in age, and includes the ammonite zones of Scaphites leei III through Baculites sp. (weak flank ribs). It includes calcareous nannofossil zone $\mathrm{CC18}$, and third-order eustatic cycle UZA3.5. The base of the Campanian is dated at $83.5 \pm 0.7 \mathrm{Ma}$ (Gradstein et al., 2004), and the Baculites obtusus ammonite zone of at the base of SCA-I is dated at $80.5 \pm 0.5 \mathrm{Ma}$ (Obradovich 1993). The duration of SCA-H is approximately 3.0 myr.

SCA-I is early middle Campanian in age, and includes ammonite zones Baculites obtusus through $B$. sp. (smooth), calcareous nannofossil zone $\mathrm{CC} 19$, the lower part of $\mathrm{CC} 20$, and the third-order eustatic cycles UZA4.1 and lower UZA4.2. At the base of the B. obtusus zone, the Ardmore bentonite from the Claggett Shale, Wyoming, is dated at 80.5 $\pm 0.5 \mathrm{Ma}$ (Obradovich, 1993), and Miller et al. (2003) provide an age estimate from the Sr-isotope curve of $81.0 \pm 0.5$ for the base of UZA4.1. The upper boundary of SCA-I is less well resolved. Miller et al. (2003) provide an Sr-isotope date of $77.8 \pm 0.5 \mathrm{Ma}$ for the top of UZA4.2, which is in lower SCA (J); the duration of SCA (I) must therefore be less than 2.7 Ma. Given a duration of 12.9 m.y. (Gradstein et al., 2004) and 23 ammonite zones, Campanian ammonite zones represent an average of $0.56 \mathrm{~m}$.y. Since only one ammonite zone (Baculites perplexus [late]) is in both SCA (J) and UZA4.2, I subtract 0.6 Ma from the 77.8 Ma age of upper UZA4.2, and propose a 2.1 myr estimate for the duration of SCA-I.

SCA-J spans the late middle Campanian, and includes the ammonite zones Baculites perplexus through B. scotti. It also includes the upper part of nannofossil zone CC20, most of CC21, and the upper portion of third-order eustatic cycle UZA4.2 and UZA4.3. The base of UZA4.3 is placed at $78.5 \pm 0.5 \mathrm{Ma}$ (Miller et al., 2003), and Obradovich (1993) reports an age of $75.9 \pm 0.5 \mathrm{Ma}$ from the $B$. scotti zone in the Lewis Shale of New Mexico. The duration of SCA-J is approximately 2.6 myr. SCA-K is early late Campanian in age, and spans the Didimoceras nebrascense through Baculites compressus ammonite zones. It includes calcareous nannofossil zone CC22 and subzone CC23a, and the lower half of third-order eustatic cycle UZA4.4. The zone of Baculites scotti, underlying the $D$. nebrascense zone, is dated at $75.9 \pm 0.7 \mathrm{Ma}$, while the base of the B. compressus zone is dated at $73.4 \pm 0.4$ based on a bentonite from the Bearpaw Shale in Montana (Obradovich, 1993). The duration of SCA $(\mathrm{K})$ is approximately $2.5 \mathrm{myr}$.

SCA-L is latest Campanian in age, and spans the ammonite zones Baculites cuneatus through B. reesidei. It includes the calcareous nannofossil subzones CC22b, and CC23a-b, and the upper portion of the third-order eustatic cycle UZA4.4. The B. compressus zone, underlying B. cuneatus has been dated at $73.4 \pm 0.4$ (Obradovich, 1993). The date for the Campanian/Maastrichtian boundary is $70.6 \pm 06 \mathrm{Ma}$ (Gradstein et al., 2004). The duration of SCA (L) is approximately 2.8 myr.

SCA-M spans the early Maastrichtian, and includes the ammonite zones Baculites baculus through B. clinobatus (Cobban et al., 1994). It also includes calcareous nannofossil subzone $\mathrm{CC} 23 \mathrm{c}$ and zone $\mathrm{CC} 24$, as well as the lower portion of third-order cycle UZA4.5. The base of the Maastrichtian is assigned a date of $70.6 \pm 0.6 \mathrm{Ma}$ (Gradstein et al., 2004), and a bentonite from above the B. clinobatus zone (top of lower Maastrichtian) in the lower Fox Hills Formation in Red Bird, Wyoming is dated at $69.4 \pm 0.4 \mathrm{Ma}$ (Obradovich, 1993). The duration of SCA-M is approximately 1.2 myr.

SCA-N is early late Maastrichtian in age, and spans the ammonite zones of Hoploscaphites birkelundi through lower Discoscaphites conradi (Cobban et al., 1994, Landman et al., 2004a,b). In the Western Interior, the highest ranging ammonite zone, Jeletzkytes nebrascensis, is at least partially correlative to the $D$. conradi zone of the Atlantic and Gulf coasts, but it is at present unknown precisely how high $J$. nebrascensis ranges (Kennedy et al., 1998). SCA (N) includes calcareous nannofossil zone $\mathrm{CC} 25 \mathrm{a}, \mathrm{b}$ and the upper portion of thirdorder eustatic cycle UZA4.5. The base of the $H$. nicolleti zone is dated at $69.4 \pm 0.4 \mathrm{Ma}$ (Obradovich, 1993). Miller et al. (2003) provide a Sr-isotope date of $67 \pm 0.5 \mathrm{Ma}$ for the top their "Navesink I sequence" (equivalent to the top of UZA4.5). Thus the duration of SCA-N is approximately 2.4 myr.

SCA-O spans the latest Maastrichtian, includes the upper portion of the ammonite zone of Discoscaphites conradi through Discoscaphites iris (Landman et al., 2004a,b), calcareous nannofossil subzone CC25c and zone CC26. Third-order eustatic cycle TA1.1 and the base of TA1.2 are included in SCA-O. The base of TA1.1 is dated at $67.0 \pm 0.5 \mathrm{Ma}$ based on Sr-isotope curves (Miller et al., 2003), and the upper boundary of SCA-O is the K/T boundary, defined by the Chixulub impact-derived Ir-anomaly and dated at $65.5 \pm 0.3 \mathrm{Ma}$ (Gradstein et al., 2004). The duration of SCA-O is approximately 1.5 myr. 